DOI: $10.20472 / E F C .2018 .010 .010$

\title{
SUDARSHAN GIRAMKAR
}

Hon. Shri Babanrao Pachpute Vichardhara Trust's, Parikrama Institute of Management., India

\section{GREEN BANKING IN INDIA: A STUDY FOR SUSTAINABLE DEVLOPMENT.}

\begin{abstract}
:
The global warming is becoming the national as well as international problem; it hampers on destroying the natural resources. For the controlling of global warming problem there should be focus on green and ecofriendly initiatives by all. Banking sector is generally considered as environmental friendly sector in terms of the pollutions and emissions. The Indian banking business is one of the largest banking business in the world which caters to the needs of different strata of society. The development of economy in all sector have the very bad impact on environment. Until the end of twentieth century, green was just the color of money for banks in India. With the introduction of Automated Teller Machines (ATMs) in 2001in the banking sector of India, banking sector took initiative towards an environment-friendly banking system. Green banking means combining operational improvements, technology and changing client habits in banking business. There is need to banks should go for green and play a pro-active role to care environmental and ecological aspects as part of their lending principle, which would force industries to go for mandated investment for environmental management. Thereafter, many initiatives were undertaken viz. use of eco-friendly papers, solar-powered ATMs, green projects, energy efficiency practices, workplace health and safety, organizing awareness campaigns, online banking systems, etc. This paper deals with the green initiatives and developments took place in the banking sector in India and sites international developments. It sites opportunities for banks in areas like carbon credit business, green financial products, core banking solutions, integrated IT environment, etc. that can lead to development in green area and overall environment. The Role of the Reserve Bank of India in formulation of policies on green banking has been focused upon for green growth.
\end{abstract}

\section{Keywords:}

Green initiatives, core banking solution, sustainable development, ecological balance, tech-world, thumb economy, green growth, etc.

JEL Classification: A10 


\section{INTRODUCTION-}

Global warming is enhancing and becoming a national and international problem since last few years. Global environmental concern of shrinking natural resources, population growth, pollution, greenhouse effect, energy shortage, effluents, etc. have affected our natural balance. Today, no sector has remained isolated from its effect. In 1987, the World Commission on Environment \& Development published its survey which mentioned that environmental fortification and growth of an economy are correlated. In an economy like India characterized by increasing globalization and over-population, society is bound to be affected by the ill-effects of development. Sustainable development is what the industries seek for. Sustainability is managing social and environmental perils in strategic decisionmaking and offering and finding opportunities for inventive product development in new areas associated to it. It can be established that environment, economy and society are the three legs of the sustainability tripod.

It is well-known that between all the sectors, banking is the largest sector which caters to the needs of different sections of society. Until the end of twentieth century, green was fair the color of currency for banks in India. The notion of corporate social responsibility (CSR) was only on documents. Environmental guard and sustainable ecological equilibrium found its way with the outline of Automated Teller Machines (ATMs) in 2001. Technology as a powerful tool has improved the quality of banking services provided and has twisted the pace to gain a strategic position in shaping the sector. Technological innovations has not only existing consumers a greater array of services but also allowed banks to devise new approaches of business transactions thereby leading to rate control (Parab, 2010). Green Banking aids in improving the asset class of banks. The concept of green banking is jointly helpful to the banks, industries and the economy.

\section{LITERATURE REVIEW}

Authors are increasingly talking about green banking and highlighting the problems and challenges the banking sector is facing in implementation of these initiatives. Rajan, 2010, focused on the role of standard minimum norms to be followed by companies to become eco-friendly. This will impose a compulsion on all organizations to behave in a socially responsible manner. Similarly, Mehta, 2009, propounded that due to factors like highly educated and demanding customers, shorter product life-cycles and growing competition, role of technology has increased in reducing environmental problems.

Parab, 2010, mentioned the advantages of mobile banking and focused on the challenges that mobile banking has to face in today's techworld viz. educating the consumers, security issues, phone compatibility to anti-virus systems, e-waste management etc. 
Prasad, 2011, has emphasized the role of three dimensions-ecological security, livelihood security and food security as the essential elements of a development policy which is both sustainable and equitable. He has argued that new technologies and scientific techniques work in harmony with the laws of nature. While talking about the concept of environmental accounting, he emphasizes the role of expenditure for environmental protection in constructing a comprehensive balance sheet of natural resources.

Bihari, 2011, has focused on the main objective of banks in the area of ecology as optimal utilization of resources and examining the effects of their lending and investment decisions on the environment. Singh, 2011, while emphasizing on role of technology, propounds the concepts of re-use, recycling and minimization of waste as ways to cope up with the environmental problems to ensure sustainable growth.

Babu \& Venkatramaraju, 2011, have given the factors for promoting eco-friendly products and services viz. educating the customers through green advertising campaigns, participation of customers through environmental-friendly action, providing genuine products and lastly, green penetration.

Bhanagade, 2011, propounded some of the competitive challenges for banking as profitability, technology in banking, risk management, rural and social banking issues, human resources management, corporate governance, transparency and disclosures, etc. 'Think global and act local' is the way forward according to him.

\section{INTERNATIONAL DEVELOPMENTS}

Goldman Sachs has been rated as the Best Investment Bank and Best M \& A (Merger and acquisition) Bank in April, 2012 by the Global Finance. Bloomberg rated Goldman Sachs as one of the 'greenest' banks in the domain. Apart from this various initiatives are took place this are as follows-

1. The Intergovernmental Panel on Climate Change (IPCC) is a systematic intergovernmental body which affords comprehensive assessments of recent scientific, technical and socio-economic material worldwide about the risk of climate change. Naturally it involves the governments of more than 120 countries.

2. Bank Tract is a global alliance of Non-Government Organizations who designed a network in 2002 to indorse sustainable finance in the commercial area.

3. The Kyoto Protocol is a protocol to the UNFCCC or FCCC, meant at hostile global warming. The Protocol was initially adopted on 11 December 1997 in Kyoto, Japan, and 
entered into force on 16 February 2005. As of September 2011, 191 countries have signed and ratified the protocol. Under the Protocol, countries bind themselves to a reduction of four greenhouse gases (GHG) produced by them.

4. The Happy Planet Index (HPI) is an index of human well-being and environmental effect that was announced by the New Economics Foundation (NEF) in July 2006. The index is planned to challenge well-established indices of countries' development, such as GDP and the Human Development Index ( $\mathrm{HDI})$, which are seen as not attractive sustainability into account.

\section{GREEN BANKING DEVELOPMENTS IN INDIA}

An awareness movement was promoted for the green reason called 'GREENATHON', by NDTV, in association with Toyota for the green object, the fourth time in a row. The website www.green.ndtv.com is meant to encourage donation towards 'Lighting a Billion Lives' i.e. lighting with the aid of solar lighting devices, with the ingenuity of The Energy and Resources Institute (TERI). This is a clear suggestion of the deepness of efforts taken in the nation for environmental guard and maintaining a sustainable natural balance.

Progressively, banks are knowingly lending to schemes that are green, opening branches that are energy-efficient and environment-friendly and by castoff paper for production cheque books. In India many public as well as private sector banks have adopted the green banking programme for sustainable development.

\section{State Bank of India:}

SBI has tossed green banking policy and set up windmills in Tamil Nadu, Maharashtra and Gujarat in producing $15 \mathrm{MW}$ power. This is the principal bank in India which is in green banking and endorsing green power projects.

\section{Punjab National Bank:}

They had taken various steps for falling secretion and energy ingesting.

\section{Bank of Baroda:}

They had taken numerous green banking initiatives such as financing a commercial project. BOB is giving preference to environment friendly green projects such as windmills, biomass and solar power projects which help in earning the carbon credits.

\section{4. $\quad$ Canara Bank:}


As a part of green banking initiative it had adopted environmental responsive measures such as mobile banking, telebanking, internet banking, and solar powered biometric processes.

\section{ICICl Bank Ltd:}

$\mathrm{ICICl}$ bank had started 'Go Green' inventiveness which involves events like Green products, green communication and Green engagement with customers.

\section{6. $\quad$ HDFC Bank Ltd:}

HDFC bank is delightful up various measures for reducing their carbon paths in waste management, paper use and energy competences.

\section{Kotak Mahindra Bank:}

Through the 'Think Green' initiative this bank had taken several initiatives such as to reduce the paper ingestion and cheering their customers to sign for e-statements and they had become partners with 'Grow- Trees.com' to plant one plantlet for every e-statement on behalf of its customers.

\section{IndusInd Bank:}

It has initiated its Green Office Project under which it had installed solar powered ATMs in different cities targeting energy saving as well as reducing $\mathrm{CO} 2$ emissions.

\section{YES Bank:}

It has plans portfolio in the areas of another energy and clean Technologies.

\section{HSBC Group:}

HSBC has separate targets for data center, paper consumption and business air travel. The resolves of the targets are to drive efficiency, reduce its active impact on the environment and generate cost savings.

\section{IDBI:}

IDBI Bank is providing various services in the field of Fresh Development Devices (CDM) to its client. 


\section{ROLE OF RESERVE BANK OF INDIA IN PROMOTING GREEN BANKING}

To highlight the Corporate Social Responsibility of banks, the RBI distributed a notice on December 20, 2007 to all scheduled commercial banks titled 'Corporate Social Responsibility, Sustainable Development and Non-Financial Reporting- Role of Banks.' The RBI also tailed many international enterprises like United Nations Environment Program Finance Initiative (UNEP-FI), Global Reporting Initiative, the Equator Principles, IFC and Declaration of Financial Organizations. The Equator Values were first declared by ten international banks from Europe, North America and Australia in June 2003 and designed to ensure that the projects financed by banks and financial organizations are socially liable and reflect sound environmental administration performs.

On October 28, 2011 Reserve Bank of India dispensed a letter to all Non-Banking Financial Corporations i.e. NBFCs titled "Implementation of Green Creativity of the Government" asking them to take steps for better operation of their resources and better delivery of amenities. This can be done by increasing the use of elimination of post-dated cheques, electronic payment systems and gradual phase-out cheques in their day to day contacts.

\section{BENCHMARK IN GREEN BANKING}

The various banks have taken the green initiatives since 2005 in the following areas like:

- Hosting, sponsoring and participating in several major conferences, attended by policy makers, NGOs and educators, as well as clients, investors and employees.

- IPO for clean technology and renewable energy

- Commitment to environmental and social stewardship

- LEED certified Real Estate

- Liquidity and risk management services for environmental commodities

- Financing green transactions

- ESG factor consideration for business decisions

For the green initiatives idea of view the five groups of Sustainable Finance awards as per Financial Times for banking sector are underway this are as follows

1. Sustainable Bank of the Year 


\section{Technology in Sustainable Finance \\ 3. Sustainable Investment of the Year \\ 4. Sustainable Investor of the Year \\ 5. Achievement in Inclusive Business}

\section{THE WAY FORWARD FOR INDIAN BANKING SECTOR}

Today, when a one gets a savings account opened in a bank, maximum of the banks deliver three passwords- one for Online-Banking, another for transacting from ATM and the third for Phone-Banking. It is a clear sign of the extent of usage of technology by banks flagging way for India to convert the 'THUMB ECONOMY'. Green banking is not merely environmental shield but customer delight saving customers' time, energy and money. People are creation use of wide variety of services through their credit card or debit card viz. making bill payments, balancing a cheque book, downloading banking transactions ,online booking, online shopping, as well as credit card transactions, verifying bank balances, money transfer, opening and closing accounts, tracking recent account activity, etc. The banks are therefore heading towards an IT enabled Customer Relationship Banking. The initiative of green banking is mutually beneficial for the banks, industries and the economy.

As according to the Happy Planet Index, India stood on 90 position in 2006 and 35 in 2009; and India's promise to cut its carbon intensity by 20 to 25 per cent by 2020 from 2005 levels, provides wonderful opportunities for banks. Here, the concept of 3Cs and 3Ps will be worth mentioning as necessary features for sustainable growth. The 3Cs stand forCost, Control and Customer Service and 3Ps stand for- People, Planet and Profit. Green banking optimizes costs, reduces the risk, enhance bank statuses and contribute to the common good of environmental sustainability. So, it serves both the commercial impartial of the bank as well as its common responsibility.

Risk is one factor which is unavoidable from banking system. Peril can be evaded by exploiting the use of opportunities in the following areas:

1. Carbon credit business- carbon credit is a credential showing that a government or company has paid to have a certain quantity of carbon dioxide removed from the environment. A carbon credit is a generic term for any tradable certificate or permit representing the right to emit one to one of carbon dioxide or the mass of alternative greenhouse gas. Many corporations sell carbon credits to commercial and 
separate customers who are interested in lowering their carbon footprints on a voluntary basis.

2. Green financial products and services like green loans, green retail banking, green credit cards, energy-efficient mortgages, corporate and investment banking, etc.

3. Carbon footprint reduction such as paperless banking, green buildings.

4. Core Banking Solutions - It is a strategic approach intended to allow banks to improve operations, reduce costing, operating expenses and be prepared for growth. An overall service-oriented-architecture helps banks reduce the risk that can result from manual data entry and increases management information and review, out-of-date information, and evades the possible disruption to business began by replacing entire systems.

5. Business Process Re-engineering - It is basically reconsidering and very redesigning an organization's existing properties. Reengineering jumps with an assessment of the customer needs. Organization's mission, and strategic goals.

6. Integrated IT environment- The banks need to deliver a suitable and up-to-date IT environment which free from safety issues. For this, the banks need to implement higher levels of security and verification such as passwords and biometric, or PINs and lengthier passwords, involving entree to customer information or the movement of funds to other parties. In addition banks need to organize awareness campaigns to provide customers with more teaching and awareness of security risks and procedures

7. Creation of dedicated pool of Human Resources- The banks need to manage the subject of employing expert personnel, training the existing employees and serving the overall growth of individuals.

8. Creation of environmental, social, or ethical investment funds- This concept relates to green financing. Such investment funds can be accessible that may be environment friendly and diminish carbon credit.

\section{Other Benefits of green banking:}

- Reduce administrative burden

- Attracting and retention of staff

- Improving the service standards 
- Drive customer loyalty

- Automation of manual tasks

- Reduce costs to serve and sell

\section{OBJECTIVES OF THE STUDY}

The study mainly aims at sympathetic the green banking attitude adoption by the banks. The paper attempts to appraisal various guidelines for environmental upkeep and sustainability along with the initiatives taken by the public and private sector banks. It is continuously important for decisions makers to know how the usage of green banking product is different among various gender, age groups and occupiers. Geographical place, accessibility of green banking products, and financial savvy also play a vital role in the adoption of green banking products. It enables the decisions creators to control which group need to be more attentive and targeted because green banking not only offers convenient to the customer but also help the banks to decrease their cost. However, due to time and money limitation, the present study only focus on tentative the association between age groups and adoption of green banking product.

\section{RESEARCH HYPOTHESES}

On the basis of aforesaid objectives, the existing study aims to test the following hypothesis:

$\mathrm{HO}$ : The mean usage of green banking products is sovereign of age.

$\mathrm{H} 1$ : The mean usage of green banking products is not independent of age.

\section{RESEARCH METHODOLOGY}

The study chiefly includes literature review from secondary data. The secondary data sources contain reports of the corresponding banks and other relative material published on the banks and other internet sites. The study also contains the primary data collection through individual visit to the bank and in-depth interviews of the customers. To test the association between adoption of green banking products and age of individuals, the succeeding methodology has been applied.

\section{DATA COLLECTION AND SAMPLE SIZE}

The data for adoption of green banking product and age pattern have been collected through designed questionnaire. The questionnaire includes thirteen question on the usage 
of green banking products, namely Solar ATMs, Green channel counters, Mobile banking, Green remit cards, Online banking, E-Investment services, Green mortgages, Green credit card, Online savings account, Green certificate of deposits, Green checking account, Bonds and mutual fund for environmental friendly project, and Recyclable debit \& credit cards. The individual usage score for each green banking product has been calculated on 5 likert point scale, where, likert scale measure frequency of usage of green banking products. The score of one represents, the product has never been used by respondent, whereas, the score of five means product is being used very often. The 112 questionnaires have been circulated personally and online through Google forms to the sample respondent. Samples are drawn from various regions of Maharashtra state.

\section{SAMPLING TECHNIQUES}

To select the sample, the following sample techniques have been used:

1) Judgmental Sampling: Judgmental sampling is a non-probability sampling technique where the researcher selects units to be sampled founded on their knowledge and professional decision.

2) Snowball Sampling: A non-probabilistic sampling technique in which an early group of respondents is selected randomly. Subsequent respondents will be selected based on the referrals or information.

3) Convenience Sampling: Convenience sampling is a non-probability sampling technique where subjects are selected because of their suitable accessibility and nearness to the researcher.

\section{STATISTICAL TECHNIQUES}

The Analysis of Variance, popularly known as the ANOVA, is used in cases where there are more than two groups. In order to test the null hypothesis, Analysis of Variance and Post hoc Multiple Comparisons test has been applied. To test the parity of variance among various age groups, Levene test has been used.

\section{DATA ANALYSIS AND RESULTS}

The descriptive statistics of mean usage of green banking products thru various age groups have been shown in Table 1. The descriptive statistics shows that the usage of green banking product is high between individuals of age groups of 15-30, with mean score of 26.51 , whereas, the usage is minimum amongst individuals of age above 60 with mean 
usage of 15 only. The standard error of the mean score for each group is between one and two, which is consistent and abstemiously low.

Table 1: Descriptive statistics of green banking product across various age group

\begin{tabular}{|l|l|l|l|l|l|l|l|l|}
\hline $\begin{array}{l}\text { Age } \\
\text { Group }\end{array}$ & $\mathbf{N}$ & Mean & $\begin{array}{l}\text { Std. } \\
\text { Deviatio } \\
\mathbf{n}\end{array}$ & $\begin{array}{l}\text { Std. } \\
\text { Error }\end{array}$ & $\begin{array}{l}\text { Lower } \\
\text { Bound } \\
(95 \% \\
\text { confidence } \\
\text { Interval for } \\
\text { Mean) }\end{array}$ & $\begin{array}{l}\text { Upper } \\
\text { Bound(95 } \\
\text { confidenc } \\
\text { e Interval } \\
\text { for Mean) }\end{array}$ & Minimum & Maximum \\
\hline $12-30$ & 66 & $\begin{array}{l}26.515 \\
2\end{array}$ & 9.09648 & 1.11970 & 24.2790 & 28.7513 & 13 & 49 \\
\hline $30-45$ & 27 & $\begin{array}{l}26.074 \\
1\end{array}$ & 7.74560 & 1.49064 & 23.0100 & 29.1381 & 13 & 49 \\
\hline $45-60$ & 15 & $\begin{array}{l}22.933 \\
3\end{array}$ & 7.38209 & 1.90605 & 18.8453 & 27.0214 & 13 & 39 \\
\hline 60 above & 4 & $\begin{array}{l}15.000 \\
0\end{array}$ & 2.30940 & 1.15470 & 11.3252 & 18.6748 & 13 & 17 \\
\hline Total & 112 & $\begin{array}{l}25.517 \\
9\end{array}$ & 8.66492 & 0.86649 & 23.8954 & 27.1403 & 13 & 49 \\
\hline
\end{tabular}

To test the hypothesis, is usage of green banking products (adoption) independent of age, ANOVA test has been conducted. The result of ANOVA test has been shown in Table 2 . The $p$ value of chi-square statistics is found to be 0.039 (less than 0.05 ), which reject our null hypothesis that usage of green banking is independent of Age. Since, ANOVA test assume variance is equal across many group age group, therefore, to test the equality of variance, Leven test1 has been applied and outcomes have been shown in Table 3.

Table 2: ANOVA results of test of equality of mean usage across various age groups

\begin{tabular}{|l|l|l|l|l|l|}
\hline & Sum of Square & df & Mean Square & F & Sig. \\
\hline Between Groups & 616.694 & 3 & 205.565 & 2.877 & .039 \\
Within Groups & 7717.270 & 108 & 71.456 & & \\
Total & 8333.964 & 111 & & & \\
\hline
\end{tabular}

Table 3: Test of Homogeneity of Variance

\begin{tabular}{|l|l|l|l|}
\hline Levene Statistics & df1 & df2 & Sig. \\
\hline 1.838 & 3 & 108 & .145 \\
\hline
\end{tabular}


The $p$ value for Levene statistics is more than 0.05 which provide evidence of equality of variance. The limitation of ANOVA is that it does not explain which group account for significant difference in the mean. If mean usage is not equal among various groups, then ANOVA is not enough to identify which group causes the inequality or for which group there exist significant alterations. Therefore, to identify which groups have significant difference in mean usage of green banking product, post hoc analysis has been performed and results have been shown in Table 4.

Table 4: Post hoc analysis of mean usage of green banking products across various ages.

\begin{tabular}{|l|l|l|l|l|l|l|}
\hline Age(I) & Age(J) & $\begin{array}{l}\text { Mean } \\
\text { Difference(I- } \\
\text { J) }\end{array}$ & Std.Error & Sig. & $\begin{array}{l}\text { Lower } \\
\text { Bound } \\
\text { (95\% } \\
\text { confidence } \\
\text { Interval for } \\
\text { Mean) }\end{array}$ & $\begin{array}{l}\text { Upper } \\
\text { Bound(95\% } \\
\text { confidence } \\
\text { Interval for } \\
\text { Mean) }\end{array}$ \\
\hline \multirow{2}{*}{$15-30$} & $30-45$ & .44108 & 1.93111 & .996 & -4.5981 & 5.4803 \\
& $45-60$ & 3.58182 & 2.41794 & .452 & -2.7277 & 9.8914 \\
& 60 Above & 11.51515 & 4.35278 & .046 & .1566 & 22.8737 \\
\hline $30-45$ & $15-30$ & -.44108 & 1.93111 & .996 & -5.4803 & 4.5981 \\
& $45-60$ & 3.14074 & 2.72218 & .657 & -3.9628 & 10.2442 \\
& 60 Above & 11.07407 & 4.52886 & .075 & -.7439 & 22.8921 \\
\hline $45-60$ & $15-30$ & -3.58182 & 2.41794 & .452 & -9.8914 & 2.7277 \\
& $30-45$ & 3.14074 & 2.72218 & .657 & -10.2442 & 3.9628 \\
& 60 Above & 7.93333 & 4.75687 & .346 & -4.4796 & 20.3463 \\
\hline 60 Above & $15-30$ & -11.51515 & 4.35278 & .046 & -22.8737 & -.1566 \\
& $30-45$ & -11.07407 & 4.52886 & .075 & -22.8921 & .7439 \\
& $45-60$ & -7.93333 & 4.75687 & .346 & -20.3463 & 4.4796 \\
\hline
\end{tabular}

*. The mean difference is significant at the 0.05 level.

The post hoc analysis shows a significant difference between age group of 15-30 and 60 above, with $p$-value of 0.046 , which is cause for difference in mean usage of green banking products across various age groups. Our results show that the usage of green banking products is not same across various age groups. The present study finds significant difference in usage of green banking products between age group of 15-30 and 60 above.

\section{LIMITATION OF THE STUDY}

The present study suffers from the following limitation: 
1) The present study only tests for usage of green banking products among various age group.

2) The results in the present study are based on sample of 112 only, which is comparatively very small as compared to the overall population.

3) To select sample, the present study has used the convenient sample. So, the results may be influenced by sampling error.

\section{CHALLENGES}

Key challenges faced by banks while implementing green banking strategies. Following are the challenges:

a) Confronting Challenges to Going Green: Green banks support pleasing causes; they do face a lot of challenges as for-profit entities. Just like those socially conscious and environmental mutual funds, they are expected to encounter more difficulties than typical run-of-the-mill bank.

b) Diversification matters: Green banks will be screening their customers and naturally, they'll be limiting and restricting their business to those entities that qualify. With a lesser pool of customers, they'll automatically have a smaller profit base to support them.

c) These banks are still startups: Apparently, it takes 3 to 4 years for a typical bank to start making money. Many green banks in business today are very new and are still in startup mode. It doesn't help that these banks are trying to get their footing during a slump.

(d) Operating expenses and costs are higher: Green banks require specialized talent, skills and expertise as well, due to the kind of customers they are servicing. Employees, such as loan officers, need to have additional related and experience in dealing with green businesses and consumers.

(e) Proper legislation is not yet framed: Government must design proper legislation of environmental instructions for banks and ensure implementation. The problems in India are the legislation is not yet framed and in few cases, things are not strictly enforced, but things can change overnight resulting in major compliance problems for the companies concerned and increased risk for the banks that have lent to them.

(f) Lack of environmental audits: Lack of environmental audits are required to regulate the environmental status of a property, facility and operation and to identify regulatory 
compliance status, past present problems and potential environmental risks and liabilities associated with the project.

\section{SUGGESTIONS}

Following are some of the suggestions that can be adopted by the banks for appropriate application of green banking in India:

a) Carbon footprint reduction by convertible energy and paper.

b) Training and development of applicable skills within bank employees so that they can use.

c) Promoting diverse forms of electronic banking.

d) Providing environment friendly prizes to customers.

e) Mark customers more and more aware about green banking through their website.

f) Creating customer's consciousness through the media.

g) By financing more and additional environment-friendly projects

\section{CONCLUSIONS}

India is the world's sixth largest and second fastest rising country in relations of creating green house gases. A major burden in operation of green initiatives by banks exists due to nonattendance of policies and regulations. In this regard, the RBI and Indian government can play a proactive role by formulating green policy guidelines. The RBI or any other regulatory expert can identify and reward the environment conscious providers of green loans on an annual basis. Green rating activities can be set up to rate the green loans, financial instruments, green funds, etc. Tax reductions can be allowed to those making green investments.

Until a few years ago, most traditional banks did not practice green banking or actively seek investment opportunities in environmentally-friendly areas or businesses. It is a common insight that it is more customary among youth, whereas less popular among aged people. Therefore, the present study test for usage of green banking habit between various age groups. The present study catches that the young generation is more inclined towards green banking products then middle age and senior age groups (above 60 years). The mean score of usage of green banking products among low age group (15-30) is 26.50, whereas, it is just 15 for individuals age above 60 . Therefore, the present study finds that 
there is more of need to create awareness about green banking products acceptance amongst the middle and senior age groups individuals than young age people. Banks needs to apply morality of sustainability and responsibility to their business model, strategy and formulation for products and services, operations and financing actions and become tougher. By adopting the environmental factors in their lending activities banks can recover the return from their investments and make the polluting industries become environmentfriendly.

\section{REFERENCES}

Babu, Suresh, R. \& Venkatramaraju, D., 2011. Focusing on the Environment - A Key Role of Greener Advertising, Advertising Express, March. Pp.19-24.

Bansal, Mona. \& Bansal, Kaveri., 2011. The Green Agenda- Role of Financial Intermediaries in Low Carbon Economy, Indian Banker. May, 6 (5). Pp.34-39.

Bhanagade, B. D., 2011. Globalization and Indian Banking: Issues, Challenges \& Strategies, Economic Challenger, July-September, 52 (13). Pp.15-20.

Bihari, S. C., 2011. Green Banking-Socially Responsible Banking in India, Indian Banker, January, 6 (1). Pp.32-37.

Mehta, Ranjeet., 2009. Digital Direct Marketing, Marketing Mastermind, October. Pp.18-20.

Parab, S, Gauri., 2010. Mobile Banking- Bringing Banking to Your Fingertips, Advertising Express, July. Pp.31-33.

Prasad, Chandra, Mahesh., 2011. World without Ends: Economics, Environment and Sustainable Development, Economic Challenger, October-December, 53 (14). Pp. 3-6.

Rajan, Thomason., 2010. Green Brands- Directions on the Next Step, Advertising Express, August. Pp.3236.

Reserve Bank of India. Circular on Implementation of Green Banking Initiative. [Online] Available at http://www.rbi.org.in/scripts/NotificationUser.aspx?ld=6783\&Mode=0 [Accessed on 17 November 2011].

Sen, Ela., 2010. Environmental Friendly Banking for Sustainable Development, Indian Banker, May, 5 (5). Pp.43-48.

Singh, Seema., 2011. Environmental Perspective in Usage of Newspaper and Shifting to E-Newspaper, Economic Challenger, October-December, 53 (14). Pp.73-77. 